\title{
THE IMPACTS OF CLIMATIC AND NON-CLIMATIC FACTORS ON HOUSEHOLD FOOD SECURITY: A STUDY ON THE POOR LIVING IN THE MALAYSIAN EAST COAST ECONOMIC REGION
}

Md. Mahmudul Alam, Chamhuri Siwar and Abu N.M. Wahid*

\begin{abstract}
Sustainable food security at the household level is a national concern in many countries. The reasons for household food insecurity include, among others, social, economic, political, and personal factors, as well as climatic changes and its outcomes. This research aims to determine the linkage of the factors of climatic changes, non-climatic factors and household resiliencies with the level of household food security among the poor and low income households in Malaysia. The present study is based on primary data that were collected in July and October 2012 through a questionnaire survey of 460 poor and low-income households from the Pahang, Kelantan, and Terengganu States of Malaysia. The sample was selected from E-Kasih poor household database based on a cluster random sampling technique. Initially the study measures household food security according to the United States Agency for International Development - Household Food Insecurity Access (USAIDHFIA) model, and has run ordinal regressions under the logit and probit models. This study finds that household food insecurity is not only linked with social and economic factors, but also significantly linked with the climatic factors. Therefore, food security programmes must be integrated with the programmes for climatic change adaptation.
\end{abstract}

Md. Mahmudul Alam, corresponding author, Senior Lecturer, School of Economics, Finance and Banking (SEFB), College of Business (COB), Universiti Utara Malaysia (UUM), Sintok, Kedah, Malaysia (e-mail: rony000@gmail.com); Chamhuri Siwar, Emeritus Professor, Institute for Environment and Development (LESTARI), National University of Malaysia (UKM), 43600 UKM Bangi, Selangor Darul Ehsan, Malaysia (e-mail: csiwar@ukm.my); and Abu N.M. Wahid, Professor, Department of Economics and Finance, Tennessee State University, Nashville, Tennessee, United States (e-mail: awahid@tnstate.edu). We are thankful to the Ministry of Science, Technology and Environment of Malaysia for generously funding the research under the Fundamental Research Grant Scheme of the Malaysian Ministry of Higher Education (FRGS/1/2012/SS07/UKM/01/3) and UKM Arus Perdana Research Grant Project (AP-2014017). 
JEL classification: I32, Q54, P48.

Keywords: Climatic changes, household food security, poverty, ordinal regression, resilience, East Coast Economic Region, Malaysia.

\section{INTRODUCTION}

The 2008 global food crisis serves as a prelude to a more acute food crisis in the future. As a result, food security is a national issue for many countries. The major food security concern is about making agricultural production sufficient for domestic consumption and having the capability to access food in the international markets.

Sustainable food security at the household level is also equally important because national food security is not enough to ensure sustainable food security at the household level. The drivers of household food security are in fact more crucial at the national level as food security is defined in its most basic form as access by all people at all times to food needed for a healthy life (FAO, 2003, p. 28). As such, the focus of food security should be on the household as the basic unit in the society. This distinction is important because activities directed towards improving household food security may be quite different from those aimed at improving food security in general.

There are many factors that drive household food insecurity. According to Lovendal and Knowles (2006), these factors include political, economic, environment, natural, social, infrastructural and health issues. Frankenberger (1992) puts forward that assets, community inequalities, risk-minimizing strategies and coping strategy are also important drivers. Nyariki and Wiggins (1997) give utilization of physical, natural, and human resources, availability of technology, and off-farm jobs as factors that drive household to food insecurity. Negatu (2006) mentions that major drivers are capability to produce one's own food and growth of purchasing power. Iram and Butt (2004), ECA (2004), Cristofar and Basiotis (1992), and Olson and others (1997) and Rose and Basiotis (1995) add household's demography, access to land, land tenure system, ability to utilize the land productively, and savings to the list of factors. Other researchers, such as Fartahun and others (2007), Hindin (2006), Myntti (1993), Pfeiffer, Gloyd and Li (2001), Piaseu (2006) and Negatu (2006), widen the list to include women with income-earning capability, women's education, sufficient income, number of children, social support, accessibility to productive resources, educational level, landholdings, accessibility to transport, livestock productivity, awareness of suitable interventions, storage technology, and unemployment level.

Changes in the climatic factors and its outcomes would also affect household food security. According to the Intergovernmental Panel on Climate Change (IPCC) 
and Fourth Assessment Report, food security and malnutrition are likely to be severely affected by climate change and variability (IPCC, 2007). FAO $(2007 ; 2008)$ has also stressed that climate change affects the availability of food, food supply stability, accessibility to food and utilization of food. This, in turn, results in negative effects on nutrition and food security. Water scarcity and droughts reduce the nutritional diversity and decrease general food consumption, which leads to malnutrition, such as micronutrient deficiencies, protein-energy malnutrition and under nutrition (IPCC, 2007). An increase in rainfall, temperature, sea levels and salinity give rise to flooding in human settlement areas (Cruz and others, 2007; Mimura and others, 2007). It may also cause scarcity of freshwater (Kundzewicz and others, 2007) and increased occurrences of diarrhea and other contagious diseases (Checkley and others, 2000; Kovats and others, 2004; Zimmerman and others, 2007). Climatic changes also affect food distribution, as it may hinder access to markets to sell or purchase food (Abdulai and CroleRees, 2001), put upward pressure on food prices (Cline, 2007; von Braun 2007) and reduce real income (Thomson and Metz, 1998).

Malaysia is a rapidly developing country with a fairly diversified economy. According to EIA (2005), carbon dioxide (CO2) emissions in Malaysia have increased by 221 per cent during the 1990-2004 period. The country is now one of the 30 largest greenhouse gas emitters. Global warming is expected to elevate the temperature by $0.3-4.5^{\circ} \mathrm{C}$. Warmer temperature will cause sea level to rise by about 95 $\mathrm{cm}$ over a hundred-year period and changes in rainfall between -30 per cent to +30 per cent. It will lead to a reduction in crop yield and cause drought in many areas, making it difficult to cultivate some crops (MOSTE, 2001). Moreover, projections indicate that maximum monthly precipitation will increase by 51 per cent in Pahang, Kelantan and Terengganu, while minimum precipitation will decrease between 32 per cent and 61 per cent for the whole Peninsular Malaysia. Consequently, annual rainfall may increase by up to 10 per cent in Kelantan, Terengganu, Pahang and North-West Coast, and decrease by up to 5 per cent in Selangor and Johor (NAHRIM, 2006). Tisdell (1996) finds that rainfall variability increases the level of environmental stress that affects the capability of the system to maintain productivity.

Under the current climate change scenario, temperatures above $25^{\circ} \mathrm{C}$ may reduce grain mass by 4.4 per cent per $1^{\circ} \mathrm{C}$ rise (Tashiro and Wardlaw, 1989), and grain yield may decline as much as by 9.6-10.0 per cent per $1^{\circ} \mathrm{C}$ rise (Baker and Allen, 1993). Singh and others (1996) reveal that the actual farm yields of rice in Malaysia vary from 3 to 5 tons per hectare, where potential yield is 7.2 tons. The study also unfolds that there is a decline in rice yield between 4.6 per cent and 6.1 per cent per $1^{\circ} \mathrm{C}$ temperature increase and a doubling of $\mathrm{CO} 2$ concentration (from present level of $340 \mathrm{ppm}$ to $680 \mathrm{ppm}$ ), which may offset the detrimental effect of a $4^{\circ} \mathrm{C}$ temperature 
increase on rice production in Malaysia. Overall, based on the analysis of minimum and maximum yield over the last 28 years, the macro cases of the Malaysian national data from 1980 to 2008 show that the yield of paddy would decrease between 43 per cent and 61 per cent if there is a $1^{\circ} \mathrm{C}$ temperature and 1 millimeter $(\mathrm{mm})$ rainfall increase (Ali and Ali, 2009). A recent study, based on the micro data on paddy field of the Integrated Agricultural Development Area (IADA), has indicated that in North-West Selangor, a temperature increase of 1 per cent may lead to a 3.44 per cent decrease in current paddy yield and a 0.03 per cent decrease in paddy yield in the following season, and that if rainfall were to increase by 1 per cent, paddy yield might decrease by 0.12 per cent and then another 0.12 per cent in the following season (Alam and others, 2014).

Malaysia joined 185 other nations in signing the Declaration of Rome at the 1996 International Food Summit, pledging to reduce the prevalence of hunger by at least 50 per cent, within its own jurisdiction by a target date sometime in the early $21^{\text {st }}$ century. However, in Malaysia, food security has been embedded into the theme of the self-sufficiency level that referred to paddy or rice sector only (Arshad, Shamsudin and Saleh, 1999; Alam and others, 2011; 2012b), instead of having a specific or special policy on overall food security. To ensure food security in Malaysia, the Government has adopted two strategies, establishing a self-sufficiency level and building rice stocks both domestically and internationally. However, the country has yet to meet the food self-sufficiency level. About 10 to 35 per cent of the total rice requirement is imported from neighbouring countries, namely India, Myanmar, Pakistan and Viet Nam. Thus far, the highest food self-sufficiency level for the country was 95 per cent, recorded in 1975, and the lowest was 65 per cent, recorded in 1990.

As climate change is one of the major potential threats to the national food security in Malaysia, there is a strong possibility that climatic change is linked to the household food security of the country. To ensure food security and proper policy options in Malaysia, it is very important to study the current situation of household food security and the linkage between the changes in climatic factors and sustainable food security at the household level. Very few studies have been conducted on the impacts of changes in climatic factors and its outcomes on household food security in Malaysia (Alam and others, 2016a; 2016b). Hence, the present paper is an attempt to conduct an in-depth study on this issue. The findings of this study may be helpful for policymakers in their efforts towards setting targets in national development plans on food security, socioeconomic betterment, poverty alleviation, and achieve Vision 2020 - to become a fully developed country by 2020 . 


\section{DATA, MODEL AND METHODOLOGY}

\section{Data collection}

For the empirical assessment, this study mostly relies on primary data collected through an extensive questionnaire survey at the household level in the East Coast Economic Region (ECER) in Malaysia. ECER was selected as the study area because it covers more than half of the Peninsular Malaysia, comprising an area of about 66,000 square kilometres that includes the states of Kelantan, Terengganu and Pahang, and the district of Mersing in Johor (figure 1). ECER is very crucial for two major reasons: (a) ECER is the most vulnerable area in Malaysia to climatic changes; and (b) the income level of this area is low and the poverty rate is high, providing a hindrance to the drive to achieve Vision 2020 (Alam and others, 2012a; ECERDC, 2007 ; 2008). The population of ECER was about 3.95 million in 2005, which represented 14.8 per cent of the total population of Malaysia. In 2004 the incidences of poverty were 10.6 per cent, 4 per cent, and 15.4 per cent in Kelantan, Pahang, and Terengganu, respectively, whereas for the country as a whole, it was 5.7 per cent, while the incidences of hard-core poverty were 1.3 per cent, 1.0 per cent, and 4.4 per cent for the three states, respectively, as compared to 1.2 per cent for the country as a whole. At that time, there were about 45,000 paddy farmers in ECER, and the average productivity per worker was 11,915 Malaysian ringgit $(\mathrm{RM})(\$ 3,135),{ }^{1}$ while the national agriculture productivity per worker was RM15,355 $(\$ 4,040){ }^{1}$

The East Coast Economic Region is mainly agricultural. In 2004, crops production covered a total area of 2.22 million ha in ECER (34.8 per cent of the Peninsular Malaysia). However, in 2008, the Government officially launched a very large project to develop five key areas - manufacturing, oil, gas and petrochemicals, tourism, agriculture and human capital development. With the objective to fastforward the inflow of foreign direct investment (FDI) and industrialization in the region; the ECER Special Economic Zone (ECER SEZ) and Malaysia-China Kuantan Industrial Park were initiated in this area. Consequently, projects worth an estimated RM112 billion in value are expected to be implemented in ECER by 2020. The ECER Special Economic Zone is expected to generate up to RM90 billion in investments and contribute RM23 billion ( $\$ 5.2$ billion) to the national GDP, as well as create 220,000 jobs, out of the 560,000 jobs identified.

The dollar amount is based on the historical Malaysian ringgit per US dollar rate of 3.8 for 2004 . 
Figure 1. Location of the study area (ECER-Malaysia)

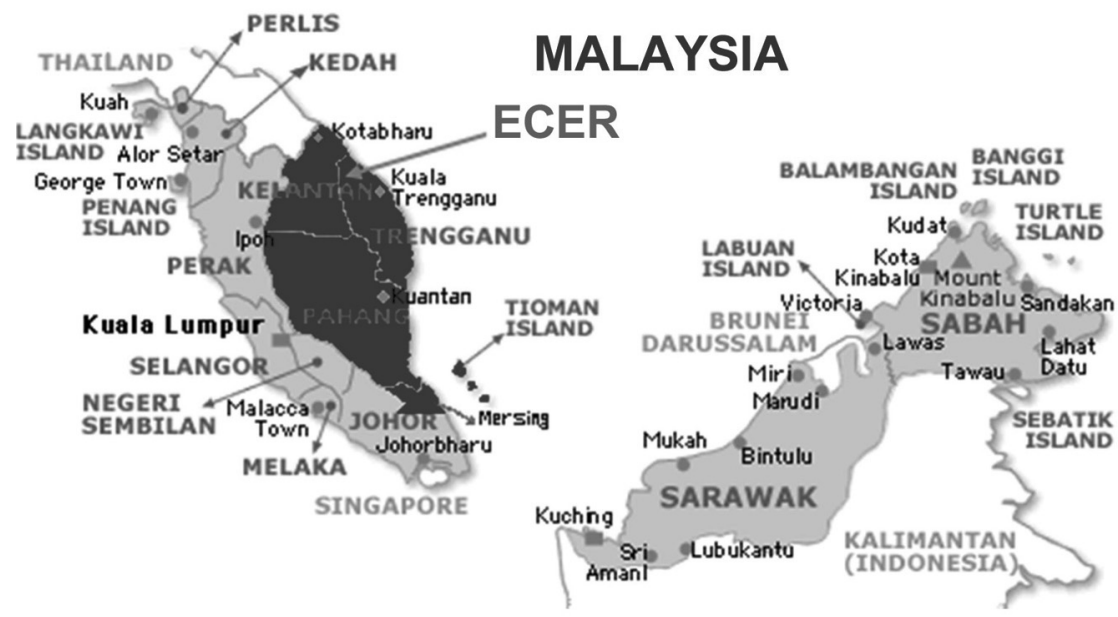

Source: Alam and others (2012a).

Note: The boundaries and names shown and the designations used on this map do not imply official endorsement or acceptance by the United Nations.

The study follows a two-stage cluster random sampling technique. Initially, the samples are clustered by location and then by poverty category. Finally, from each category, samples are picked randomly from the E-Kasih database, which is an integrated database system that enlists poor households at the national level to plan, implement and monitor poverty programmes. The urban area of Kuantan and rural area of Pekan were selected in Pahang State. The urban area of Kota Bharu and rural area of Tumpat were chosen from Kelantan State. The urban area of Kuala Terengganu and rural area of Marang were included from Terengganu State.

Based on the formula of required size of samples (Yamane, 1967, p. 886), first, 400 households are selected according to the proportion of population distribution. However, to ensure a good number of observations for each group, which is needed to conduct a sound statistical analysis for any particular group, another 100 households have been added to the sample. However, while targeting the sample size to be 500, after collecting and validating the data, 460 households remain in the sample. The final distribution of the collected sample is given in table 1. 


\section{Table 1. Distribution of the sample of the study}

\begin{tabular}{|c|c|c|c|c|c|c|c|c|c|}
\hline & \multicolumn{2}{|c|}{ Pahang } & \multicolumn{2}{|c|}{ Kelantan } & \multicolumn{2}{|c|}{ Terengganu } & \multicolumn{2}{|c|}{ Total } & \multirow{2}{*}{$\begin{array}{c}\text { All } \\
\text { Total }\end{array}$} \\
\hline & Urban & Rural & Urban & Rural & Urban & Rural & Urban & Rural & \\
\hline Hard-core poor & 2 & 15 & 33 & 22 & 6 & 32 & 41 & 69 & 110 \\
\hline Poor & 12 & 14 & 21 & 34 & 27 & 46 & 60 & 94 & 154 \\
\hline Recently marginally non-poor & 11 & 9 & 15 & 16 & 4 & 16 & 30 & 41 & 71 \\
\hline Marginally non-poor & 18 & 30 & 32 & 25 & 4 & 16 & 54 & 71 & 125 \\
\hline Total target group & 43 & 68 & 101 & 97 & 41 & 110 & 185 & 275 & 460 \\
\hline State total & \multicolumn{2}{|c|}{111} & \multicolumn{2}{|c|}{198} & \multicolumn{2}{|c|}{151} & \multicolumn{2}{|c|}{460} & \\
\hline
\end{tabular}

Note: * In the E-Kasih system, the rural poverty data were categorized as monthly income per person: up to RM110 was hard-core poor, up to RM185 was poor, and up to RM227 was marginally non-poor, and for urban area up to RM120 was hard-core poor, up to RM200 was poor, and up to RM340 was marginally non-poor.

A face-to-face interview based on a structured questionnaire is used to collect data. The survey was conducted by the regular enumerators of the Implementation Coordination Unit (ICU) agency from Pahang, Kelantan, and Terengganu during July and October in 2012.

\section{Model specification}

To measure the relationship between household status of food security and the climatic and general factors affecting on food security, the following ordered dependent regression or ordinal regression is conducted based on logit and probit models:

$$
\begin{aligned}
& Z_{i}=(Y 1, Y 2) \\
& X_{i}=(X 1, \ldots, X 63) \\
& Z_{i}=f\left(X_{i}\right)
\end{aligned}
$$

In the study, the two dependent variables, the household status of food accessibility and household food availability, are used as the measurements of household food security. Household food availability is based on measurement on the direct perception of the household, while household status of food accessibility measurement is based on the frequency of calculation. To measure the status of household food availability, households are asked about their food status in the previous month (see table 2). To measure the status of household food accessibility, this study applies direct measuring questionnaire-based techniques developed by Coates, Swindale and Bilinsky (2007) for United States Agency for International 
Development (USAID), which is known as Household Food Insecurity Access (HFIA) (table 3).

The list of the independent variables of the study (see appendix) consists of different resilience factors of a household (X1-X18), non-climatic factors (X18-X44) and climatic factors $(X 45-X 63)$. These variables are considered from the four dimensions of food security - availability of food, stability of supply, accessibility to food, and utilization of food (FAO, 2005; 2008). The availability of food means sufficient quantities of quality food available at the household level. The accessibility of food means household's access to sufficient resources, including a set of the commodity bundles that an individual can access based on the legal, economic, political, and social arrangement of a community in which they live for getting quality foods for a nutritious meal. Food utilization shows the significance of non-food inputs in food security, such as proper diet, clean water, health care and sanitation, to gain nutritional well-being in which all physiological requirements are met. Food system stability refers to households having access to sufficient food at all times even to the point that they would have access to food during a sudden crisis, such as one that is economic or climate-related, or a cyclical occurrence, such as seasonal food insecurities. Here, the resilience refers to the households' capacity or strength to cope with stress and hardship in case of actual or expected food insecurity, which are categorized as socioeconomic, physical assets, and livelihood strategy and behaviour. The measurements of all variables are given in the appendix.

To check the best fit model and robustness, the study reports both the probit and logit models, but for analysis, it mostly focuses on the logit model. Logit and probit models that look like a sigmoid function with a domain between 0 and 1, which makes them both quantile functions based on the assumption that the logit model follows logistic distribution and the probit model follows a normal distribution. Normally, the logit model is used when every observation has equal probability. Furthermore, a correlation analysis is undertaken to determine the relationship among the relevant variables and to check the multicollinearity problem. Finally, this study also justifies how the endogeneity and causality problems are considered.

\section{RESULTS AND DISCUSSION}

\section{Measurement of household food security}

In terms of household food availability, 14.8 per cent stated that they had enough food that they liked, but a large number of the households (41.1 per cent) indicated that they did not always have enough food that they liked, while 9.1 per cent of the households stated that they frequently remained hungry (table 2). 


\section{Table 2. Family food status in the previous month}

\begin{tabular}{lcc}
\hline \multicolumn{1}{c}{ Food status in the family } & No. of households & \% of total \\
\hline Enough of the kinds of food you want to eat & 68 & 14.8 \\
Enough but not always the kinds of food you want to eat & 189 & 41.1 \\
Sometimes not enough to eat & 100 & 21.7 \\
Often not enough to eat & 61 & 13.3 \\
Frequently hungry & 42 & 9.1 \\
\hline Total & $\mathbf{4 6 0}$ & $\mathbf{1 0 0 . 0}$ \\
\hline
\end{tabular}

Household food insecurity access (calculated for each household by assigning a code $1-4$, where $1=$ food secure access, $2=$ mildly food insecure access, $3=$ moderately food insecure access, $4=$ severely food insecure access. Initially, the data are coded frequency-of-occurrence as 0 for all cases where the answer to the corresponding occurrence question is "no", namely if Q1 $=0$, then Q1a $=0$, etc.). Then, the intensities of the occurrence of nine questions are measured in three frequencies - rarely (1-2 times per month) or sometimes (3-10 times) or often (10+ times per month) - which is indicated by Q1a to Q9a (table 3). Finally, the four food accessibility categories are created sequentially to ensure that households are classified according to their most severe response.

- Category $=1$ if $[(\mathrm{Q} 1=0$ or $\mathrm{Q} 1=1)$ and $\mathrm{Q} 2=0$ and $\mathrm{Q} 3=0$ and $\mathrm{Q} 4=0$ and $\mathrm{Q} 5=0$ and $\mathrm{Q} 6=0$ and $\mathrm{Q} 7=0$ and $\mathrm{Q} 8=0$ and $\mathrm{Q9}=0$ ]

- Category $=2$ if $[(\mathrm{Q} 1 \mathrm{a}=2$ or $\mathrm{Q} 1 \mathrm{a}=3$ or $\mathrm{Q} 2 \mathrm{a}=1$ or $\mathrm{Q} 2 \mathrm{a}=2$ or $\mathrm{Q} 2 \mathrm{a}=3$ or $\mathrm{Q} 3 \mathrm{a}=1$ or $\mathrm{Q} 4 \mathrm{a}=1$ ) and $\mathrm{Q} 5=0$ and $\mathrm{Q} 6=0$ and $\mathrm{Q} 7=0$ and $\mathrm{Q} 8=0$ and $\mathrm{Q9}=0]$

- Category $=3$ if $[(\mathrm{Q} 3 \mathrm{a}=2$ or $\mathrm{Q} 3 \mathrm{a}=3$ or $\mathrm{Q} 4 \mathrm{a}=2$ or $\mathrm{Q} 4 \mathrm{a}=3$ or $\mathrm{Q} 5 \mathrm{a}=1$ or $\mathrm{Q} 5 \mathrm{a}=2$ or $\mathrm{Q} 6 \mathrm{a}=1$ or $\mathrm{Q} 6 \mathrm{a}=2$ ) and $\mathrm{Q} 7=0$ and $\mathrm{Q} 8=0$ and $\mathrm{Q} 9=0]$

- Category $=4$ if $[\mathrm{Q} 5 \mathrm{a}=3$ or $\mathrm{Q} 6 \mathrm{a}=3$ or $\mathrm{Q} 7 \mathrm{a}=1$ or $\mathrm{Q} 7 \mathrm{a}=2$ or $\mathrm{Q7a}=3$ or $\mathrm{Q} 8 \mathrm{a}=1$ or $\mathrm{Q} 8 \mathrm{a}=2$ or $\mathrm{Q} 8 \mathrm{a}=3$ or $\mathrm{Q} 9 \mathrm{a}=1$ or $\mathrm{Q} 9 \mathrm{a}=2$ or $\mathrm{Q9a}=3]$

The following table illustrates the above four categorizations in which every household is placed in a unique category based on the set of the responses (table 3).

Based on the survey, this study finds that 52.8 per cent of the households are under the category of "food secure access". Among the surveyed households, 
23.3 per cent are facing mildly food insecurity (access), who are worried about not having enough food sometimes or often, and/or are unable to eat preferred foods, and/or rarely eat a more monotonous diet than desired and/or also rarely eat some undesirable foods (table 4).

\section{Table 3. Measurement of the Household Food Insecurity Access Scale (HFIAS)}

\begin{tabular}{|c|c|c|c|}
\hline \multirow[b]{2}{*}{ HFIAS measurement issues } & \multicolumn{3}{|c|}{ Category of food insecurity (access) } \\
\hline & $\begin{array}{c}\text { Rarely } \\
\text { (1-2 times } \\
\text { per month) }\end{array}$ & $\begin{array}{l}\text { Sometimes } \\
\text { (3-10 times) }\end{array}$ & $\begin{array}{c}\text { Often } \\
\text { (10+ times } \\
\text { per month) }\end{array}$ \\
\hline Q1 Worry about food & & & \\
\hline Q2 Unable to eat prefer food & & & \\
\hline Q3 Eat just a few kinds of foods & & & \\
\hline Q4 Eat foods they really do not want eat & & & \\
\hline Q5 Eat a smaller meal & & & \\
\hline Q6 Eat fewer meals in a day & & & \\
\hline Q7 No food of any kinds in the household & & & \\
\hline Q8 Go to sleep hungry & & & \\
\hline Q9 Go through the whole day and night without eating & & & \\
\hline Food secure access & $\begin{array}{l}\text { Mildly food } \\
\text { insecure }\end{array}$ & $\begin{array}{l}\text { Moderately } \\
\text { food insecure }\end{array}$ & $\begin{array}{l}\text { Severely food } \\
\text { insecure }\end{array}$ \\
\hline
\end{tabular}

Sources: Coates, Swindale and Bilinsky (2007); Alam and others (2016b).

Table 4. Distribution of Household Food Insecurity Access (HFIA)

\begin{tabular}{lcc}
\hline \multicolumn{1}{c}{ HFIA category } & HFIA prevalence & \% of HFIA prevalence \\
\hline 1 = Food secure access & 243 & 52.8 \\
2 = Mildly food insecure access & 107 & 23.3 \\
3 = Moderately food insecure access & 66 & 14.3 \\
4 = Severely food insecure access & 44 & 9.6 \\
\hline Total & $\mathbf{4 6 0}$ & $\mathbf{1 0 0 . 0}$ \\
\hline
\end{tabular}

Among the households, 14.3 per cent are moderately food insecure. These households frequently sacrifice quality of food by eating a monotonous diet or undesirable foods sometimes or often, and/or reduce eating the quantity of food rarely or sometimes. Some 9.6 per cent of households are severely food insecure and consequently, need to cut back on meal size or the number of meals, and/or 
experience any of the three most severe conditions - running out of food, going to bed hungry or going a whole day and night without eating.

\section{Household status of food security and relevant factors}

The regression models based on equation 1 show that some of the resilience factors have a statistically significant relationship with household food availability and food accessibility (table 5). The P-values of the likelihood ratio (LR) statistics for both models, which are shown below at 0.0000001 , suggest a very good fit of the models. The pseudo R-squares are 0.354 for food availability and 0.305 for the food accessibility models.

Results for household food availability (Y1) models indicate that the climatic impacts on kitchen environment (X58) and sanitation system (X60) are statistically significant. Among the non-climatic/general factors, competition for common resources (X31), common resources dependency for cattle or livestock feeding (X30), incidences of diseases, such as dengue, malaria, heat stretch, cold and skin disease (X44), having knowledge about taking precaution against dengue, malaria (X17), buying bulk amount of food (X12), household poverty/economic status (X3), earning ratio (X6), and number of school going children (X2) are statistically significant.

\section{Table 5. Relationship between household status of food security and relevant climatic and non-climatic/general factors}

\begin{tabular}{|c|c|c|c|c|c|c|c|c|}
\hline \multirow{3}{*}{ Variable } & \multicolumn{4}{|c|}{ Dependent variable Y1 } & \multicolumn{4}{|c|}{ Dependent variable Y2 } \\
\hline & \multicolumn{2}{|c|}{ Ordered probit } & \multicolumn{2}{|c|}{ Ordered logit } & \multicolumn{2}{|c|}{ Ordered probit } & \multicolumn{2}{|c|}{ Ordered logit } \\
\hline & $\begin{array}{l}\text { Odds } \\
\text { ratio }\end{array}$ & Prob. & $\begin{array}{l}\text { Odds } \\
\text { ratio }\end{array}$ & Prob. & $\begin{array}{l}\text { Odds } \\
\text { ratio }\end{array}$ & Prob. & $\begin{array}{c}\text { Odds } \\
\text { ratio }\end{array}$ & Prob. \\
\hline \multicolumn{9}{|c|}{ Household resilience factors: socioeconomic } \\
\hline $\mathrm{X} 1$ & 1.114 & 0.449 & 1.302 & 0.318 & 0.994 & 0.956 & 1.004 & 0.981 \\
\hline $\mathrm{X} 2$ & $0.722^{*}$ & 0.007 & $0.528^{\star}$ & 0.005 & $0.652^{*}$ & 0.000 & $0.486^{*}$ & 0.000 \\
\hline $\mathrm{X} 3$ & $0.739^{*}$ & 0.002 & $0.590^{\star}$ & 0.003 & $0.821^{*}$ & 0.004 & $0.719^{*}$ & 0.005 \\
\hline$X 4$ & 1.264 & 0.467 & 1.822 & 0.306 & $2.315^{\star}$ & 0.002 & $4.191^{*}$ & 0.002 \\
\hline X5 & 0.982 & 0.964 & 0.846 & 0.828 & 0.865 & 0.558 & 0.760 & 0.521 \\
\hline X6 & 1.181 & 0.136 & $1.412^{\star \star \star}$ & 0.092 & $1.385^{*}$ & 0.001 & $1.800^{*}$ & 0.001 \\
\hline $\mathrm{X} 7$ & 1.193 & 0.542 & 1.404 & 0.521 & $1.489^{\star \star \star}$ & 0.093 & 1.811 & 0.146 \\
\hline \multicolumn{9}{|c|}{ Household resilience factors: physical assets } \\
\hline X8 & 0.830 & 0.467 & 0.690 & 0.430 & 1.275 & 0.195 & 1.473 & 0.222 \\
\hline X9 & 1.065 & 0.825 & 1.017 & 0.974 & 1.289 & 0.210 & 1.466 & 0.278 \\
\hline $\mathrm{X} 10$ & 0.857 & 0.294 & 0.741 & 0.263 & 1.044 & 0.684 & 1.104 & 0.592 \\
\hline $\mathrm{X} 11$ & 1.445 & 0.176 & 1.801 & 0.232 & $1.797^{\star}$ & 0.002 & $2.769^{*}$ & 0.001 \\
\hline
\end{tabular}


Table 5. (continued)

\begin{tabular}{|c|c|c|c|c|c|c|c|c|}
\hline \multirow{3}{*}{ Variable } & \multicolumn{4}{|c|}{ Dependent variable $\mathbf{Y 1}$} & \multicolumn{4}{|c|}{ Dependent variable Y2 } \\
\hline & \multicolumn{2}{|c|}{ Ordered probit } & \multicolumn{2}{|c|}{ Ordered logit } & \multicolumn{2}{|c|}{ Ordered probit } & \multicolumn{2}{|c|}{ Ordered logit } \\
\hline & $\begin{array}{l}\text { Odds } \\
\text { ratio }\end{array}$ & Prob. & $\begin{array}{l}\text { Odds } \\
\text { ratio }\end{array}$ & Prob. & $\begin{array}{l}\text { Odds } \\
\text { ratio }\end{array}$ & Prob. & $\begin{array}{l}\text { Odds } \\
\text { ratio }\end{array}$ & Prob. \\
\hline \multicolumn{9}{|c|}{ Household resilience factors: livelihood strategy and behaviour } \\
\hline $\mathrm{X} 12$ & $2.098^{*}$ & 0.006 & $4.046^{*}$ & 0.006 & 1.057 & 0.754 & 1.080 & 0.796 \\
\hline $\mathrm{X} 13$ & 1.074 & 0.623 & 1.144 & 0.631 & 1.051 & 0.634 & 1.091 & 0.624 \\
\hline $\mathrm{X} 14$ & 1.220 & 0.221 & 1.444 & 0.220 & 1.194 & 0.153 & 1.333 & 0.182 \\
\hline $\mathrm{X} 15$ & 0.782 & 0.269 & 0.632 & 0.274 & 1.119 & 0.456 & 1.202 & 0.478 \\
\hline $\mathrm{X} 16$ & 1.085 & 0.616 & 1.139 & 0.665 & 1.049 & 0.683 & 1.074 & 0.724 \\
\hline $\mathrm{X} 17$ & $1.673^{\star \star}$ & 0.039 & $2.602^{\star \star}$ & 0.035 & 1.026 & 0.851 & 1.058 & 0.809 \\
\hline \multicolumn{9}{|c|}{ Non-climatic factors } \\
\hline $\mathrm{X} 18$ & 0.839 & 0.318 & 0.657 & 0.182 & 1.035 & 0.775 & 1.028 & 0.892 \\
\hline X19 & 1.212 & 0.201 & 1.475 & 0.165 & 1.022 & 0.851 & 1.041 & 0.836 \\
\hline X20 & 1.222 & 0.228 & 1.500 & 0.194 & 0.992 & 0.944 & 0.994 & 0.977 \\
\hline $\mathrm{X} 21$ & 1.079 & 0.677 & 1.144 & 0.688 & 1.051 & 0.675 & 1.109 & 0.603 \\
\hline X22 & 0.828 & 0.299 & 0.676 & 0.234 & $0.791^{\star \star \star}$ & 0.079 & $0.663^{\star \star \star}$ & 0.073 \\
\hline $\mathrm{X} 23$ & 1.114 & 0.495 & 1.246 & 0.444 & $0.760^{\star \star}$ & 0.018 & $0.630^{\star *}$ & 0.019 \\
\hline X24 & 1.087 & 0.485 & 1.169 & 0.473 & 0.947 & 0.543 & 0.936 & 0.660 \\
\hline X25 & 1.168 & 0.301 & 1.417 & 0.219 & 1.038 & 0.740 & 1.077 & 0.697 \\
\hline X26 & 0.873 & 0.290 & 0.772 & 0.268 & $0.809^{* *}$ & 0.022 & $0.682^{* *}$ & 0.016 \\
\hline $\mathrm{X} 27$ & 1.075 & 0.657 & 1.155 & 0.624 & 1.100 & 0.385 & 1.183 & 0.365 \\
\hline X28 & 0.933 & 0.649 & 0.876 & 0.645 & 0.945 & 0.617 & 0.913 & 0.631 \\
\hline X29 & 1.235 & 0.123 & 1.355 & 0.221 & 0.917 & 0.401 & 0.846 & 0.349 \\
\hline X30 & $1.343^{\star \star}$ & 0.041 & $1.823^{\star *}$ & 0.025 & 0.967 & 0.751 & 0.927 & 0.674 \\
\hline X31 & $0.803^{\star \star *}$ & 0.092 & $0.662^{\star \star \star}$ & 0.076 & 1.127 & 0.227 & 1.246 & 0.199 \\
\hline X32 & 1.084 & 0.526 & 1.133 & 0.600 & 1.023 & 0.830 & 1.046 & 0.807 \\
\hline X33 & 0.855 & 0.302 & 0.710 & 0.226 & 1.062 & 0.598 & 1.140 & 0.504 \\
\hline X34 & 0.820 & 0.252 & 0.693 & 0.245 & 0.840 & 0.211 & 0.763 & 0.259 \\
\hline X35 & 1.121 & 0.527 & 1.288 & 0.451 & 0.877 & 0.369 & 0.755 & 0.268 \\
\hline X36 & 0.935 & 0.680 & 0.877 & 0.661 & 0.833 & 0.130 & 0.731 & 0.127 \\
\hline X37 & 0.959 & 0.786 & 0.919 & 0.764 & 1.175 & 0.177 & 1.328 & 0.164 \\
\hline X38 & 1.148 & 0.418 & 1.200 & 0.565 & 1.180 & 0.190 & 1.319 & 0.197 \\
\hline X39 & 1.084 & 0.530 & 1.240 & 0.371 & 1.068 & 0.463 & 1.124 & 0.447 \\
\hline X40 & 0.803 & 0.186 & 0.661 & 0.166 & 0.909 & 0.407 & 0.872 & 0.482 \\
\hline X41 & 0.833 & 0.130 & 0.708 & 0.124 & 1.140 & 0.214 & 1.267 & 0.184 \\
\hline X42 & 0.983 & 0.881 & 0.960 & 0.843 & 1.131 & 0.136 & 1.253 & 0.109 \\
\hline
\end{tabular}


Table 5. (continued)

\begin{tabular}{|c|c|c|c|c|c|c|c|c|}
\hline \multirow{3}{*}{ Variable } & \multicolumn{4}{|c|}{ Dependent variable $\mathrm{Y} 1$} & \multicolumn{4}{|c|}{ Dependent variable Y2 } \\
\hline & \multicolumn{2}{|c|}{ Ordered probit } & \multicolumn{2}{|c|}{ Ordered logit } & \multicolumn{2}{|c|}{ Ordered probit } & \multicolumn{2}{|c|}{ Ordered logit } \\
\hline & $\begin{array}{l}\text { Odds } \\
\text { ratio }\end{array}$ & Prob. & $\begin{array}{l}\text { Odds } \\
\text { ratio }\end{array}$ & Prob. & $\begin{array}{l}\text { Odds } \\
\text { ratio }\end{array}$ & Prob. & $\begin{array}{c}\text { Odds } \\
\text { ratio }\end{array}$ & Prob. \\
\hline$\times 43$ & 0.761 & 0.166 & 0.591 & 0.145 & $1.503^{\star}$ & 0.001 & $2.024^{*}$ & 0.001 \\
\hline $\mathrm{X} 44$ & $1.817^{\star}$ & 0.001 & $3.179^{*}$ & 0.001 & $0.839^{\star \star \star}$ & 0.102 & $0.741^{\star \star \star}$ & 0.098 \\
\hline \multicolumn{9}{|l|}{ Climatic factors } \\
\hline X45 & 0.866 & 0.311 & 0.797 & 0.385 & $0.844^{\star \star \star}$ & 0.098 & $0.747^{\star \star \star}$ & 0.094 \\
\hline $\mathrm{X} 46$ & 0.688 & 0.152 & 0.465 & 0.126 & $0.489^{*}$ & 0.000 & $0.303^{*}$ & 0.000 \\
\hline $\mathrm{X} 47$ & 0.868 & 0.338 & 0.752 & 0.297 & 0.847 & 0.137 & 0.757 & 0.142 \\
\hline $\mathrm{X} 48$ & 1.308 & 0.221 & 1.450 & 0.344 & $1.631^{*}$ & 0.001 & $2.269^{*}$ & 0.001 \\
\hline X49 & 0.981 & 0.924 & 1.104 & 0.794 & 0.806 & 0.153 & 0.695 & 0.160 \\
\hline X50 & 1.061 & 0.722 & 1.046 & 0.888 & 0.980 & 0.873 & 0.979 & 0.919 \\
\hline $\mathrm{X} 51$ & 0.946 & 0.682 & 0.899 & 0.675 & 1.059 & 0.565 & 1.129 & 0.487 \\
\hline$x 52$ & 1.060 & 0.648 & 1.150 & 0.537 & 0.996 & 0.968 & 0.983 & 0.917 \\
\hline X53 & 1.003 & 0.983 & 1.035 & 0.888 & 1.114 & 0.303 & 1.195 & 0.313 \\
\hline X54 & 0.906 & 0.471 & 0.840 & 0.498 & 0.906 & 0.325 & 0.855 & 0.366 \\
\hline X55 & 1.212 & 0.213 & 1.483 & 0.154 & 1.061 & 0.626 & 1.109 & 0.616 \\
\hline X56 & 0.857 & 0.344 & 0.757 & 0.337 & 1.055 & 0.665 & 1.075 & 0.728 \\
\hline$X 57$ & 0.985 & 0.926 & 0.972 & 0.921 & 0.935 & 0.591 & 0.892 & 0.595 \\
\hline$X 58$ & $0.564^{*}$ & 0.002 & $0.329^{*}$ & 0.001 & 0.832 & 0.150 & 0.718 & 0.132 \\
\hline X59 & 1.358 & 0.100 & 1.690 & 0.114 & 1.032 & 0.823 & 1.073 & 0.770 \\
\hline $\mathrm{X} 60$ & $1.357^{\star \star}$ & 0.046 & $1.828^{\star \star}$ & 0.035 & 1.210 & 0.104 & $1.403^{\star \star \star}$ & 0.099 \\
\hline $\mathrm{X} 61$ & 0.811 & 0.153 & 0.680 & 0.147 & 0.876 & 0.218 & 0.787 & 0.192 \\
\hline $\mathrm{X} 62$ & 0.802 & 0.152 & 0.692 & 0.192 & 0.837 & 0.104 & $0.731^{\star \star \star}$ & 0.091 \\
\hline $\mathrm{X} 63$ & 0.889 & 0.331 & 0.801 & 0.305 & 1.113 & 0.266 & 1.189 & 0.291 \\
\hline Pseudo R-squared & \multicolumn{2}{|c|}{0.350} & \multicolumn{2}{|c|}{0.354} & \multicolumn{2}{|c|}{0.306} & \multicolumn{2}{|c|}{0.305} \\
\hline Prob (LR statistic) & \multicolumn{2}{|c|}{$<0.0000001$} & \multicolumn{2}{|c|}{$<0.0000001$} & \multicolumn{2}{|c|}{$<0.0000001$} & \multicolumn{2}{|c|}{$<0.0000001$} \\
\hline Sample size & \multicolumn{2}{|c|}{460} & \multicolumn{2}{|c|}{460} & \multicolumn{2}{|c|}{460} & \multicolumn{2}{|c|}{460} \\
\hline
\end{tabular}

Note: $\quad{ }^{*},{ }^{* *},{ }^{* *}$ indicates significant at $1 \%, 5 \%, 10 \%$ significance level, respectively.

In terms of odds ratios, results from the availability of food at household (Y1) logit model indicates that holding other things constant, for a unit increase in the common resources dependency for cattle or livestock feeding (X30), the odds in favour of availability of food at household (Y1) increases by 1.823 , or about 82.3 per cent. Similarly, there is a 160.2 per cent increase of odds of availability of food for the household $(\mathrm{Y} 1)$ for a one-unit increase in knowledge about taking precaution against 
dengue, malaria (X17). The odds of household food availability (Y1) for a household buying bulk amount of food (X12) is 304.6 per cent higher than the odds of household food availability (Y1) for a household without buying a bulk amount of food. For a unit increase in the earning ratio (X6), the odds in favour of availability of food at household (Y1) increases by 1.412 or about 41.2 per cent.

Holding other things constant, a unit increase in climatic issues affecting the kitchen environment (X58) increases the odds in favour of unavailability of food in the household (Y1) by (1-0.329), or about 67.1 per cent. Similarly, there is a 33.8 per cent increase of odds of unavailability of food at the household (Y1) for a one-unit increase in competition for common resources (X31). For a unit increase in poverty level or decrease of household poverty/economic status (X3), the odds in favour of unavailability of food at a household (Y1) increases by (1-0.59), or about 41 per cent. Similarly, there is a 47.2 per cent increase of odds of unavailability of food at household (Y1) for a one-unit increase in number of school going children (X2).

Results for household status of food accessibility (Y2) models show that, among the climatic factors, natural disasters at the local level (X45), and climatic impact on income (X46), climatic impact on household food storage system (X48), climatic impact on household sanitation system (X60), and climatic impact on increases of short term food prices (X62) are statistically significant. Among the nonclimatic/general factors, prices of general food items (X22), the difference between rural and city food prices (X23), low level of income (X26), incidences of mosquitoes, insects, pest (X43), incidences of disease (X44), household transportation (X11), household poverty/economic status (X3), earning ratio (X6), spouse doing job (X4), and number of school going children (X2) are statistically significant. According to the probit model, households having savings (X7) also show a statistically significant relationship with household status of food accessibility.

With reference to the food accessibility at household (Y2) logit model, the odds ratio indicate that holding other things constant, for a unit increase in climatic impact on household food storage system (X48), the odds in favour of food security at the household (Y2) increases by 2.269 or about 126.9 per cent. Similarly, there is an 80 per cent increase of odds of food accessibility at household (Y2) for a one-unit increase in earning ratio (X6). The odds of household food accessibility (Y2) for household having transportation $(\mathrm{X} 11)$ is 176.9 per cent higher than the odds of household without having transportation. The odds of household accessibility (Y2) for spouse being employed (X4) is 319.1 per cent higher than the odds of household without spouse doing job. The odds of household food accessibility (Y2) for household have savings (X7) is 48.9 per cent higher than the odds of household without having savings. 
For this model, the odds on climatic factors indicate that holding other things constant, for a unit increase in natural disasters at the local level (X45), the odds in favour of food accessibility at a household (Y2) decreases by (1-0.747) or about 25.3 per cent. Similarly, there is a 69.7 per cent decrease of odds of food accessibility at household (Y2) for a one-unit increase in climatic impact on income (X46). For a unit increase in climatic impact on increases of short-time food prices (X62), the odds in favour of food accessibility at a household (Y2) decreases by (1-0.731), or about 26.9 per cent. Similarly, there is a 33.7 per cent decrease of odds of food accessibility at a household (Y2) for a one-unit increase in prices of general food items (X22). For a unit increase in difference between rural and city food prices (X23), the odds in favour of food accessibility at a household (Y2) decreases by (1-0.63) or about 37 per cent. Similarly, there is a 31.8 per cent decrease of odds of food accessibility at a household (Y2) for a one-unit increase in low level of income (X26). For a unit increase in incidences of disease (X44), the odds in favour of food accessibility at a household (Y2) decreases by (1-0.741) or about 25.9 per cent. Similarly, there is a 28.1 per cent decrease of odds of food accessibility at a household (Y2) for a one-unit increase in household poverty/economic status (X3). For a unit increase in number of school going children (X2), the odds in favour of food accessibility at household (Y2) decreases by (1-0.486) or about 51.4 per cent.

However, in the model, some of the variables show unexpected signs with respect to their relationship with household food security, such as the climatic impacts on sanitation system (X60), and the incidences of disease (X44) show the odds in favour of availability of food at a household (Y1). Similarly, the climatic impact on household sanitation system (X60) and incidences of, for example of mosquitoes, insects and pests (X43), show the odds in favour of food accessibility at a household (Y2). Therefore, new additional studies need to be undertaken to justify the unusual behaviour of these few variables.

\section{Model efficiency test}

To test the presence of multicollinearity among the variables, the Pearson Correlation tests have been performed in the study. When two variables are considered highly correlated to each other in explaining the dependent variable, it may give rise to multicollinearity problem. In the case of multicollinearity, the correlation value is considered as 0.8 or above (Field, 2000, pp. 2, 44-322). The result shows that the correlation values among the variables fall below 0.8 , which indicates that multicollinearity problem is absent among the variables.

Moreover, logically this study is free from endogeneity (including causality) problem because in the survey, questions were asked about the impact of different 
factors on food security and not vice versa. Moreover, technically the ordered dependent regression or ordinal regression is based on the "Generalized Linear Models" (used by EViews statistical package) and "Generalized structural equation model" (used by Stata statistical package) in which the software itself takes some instrumental variables to solve the endogeneity problems.

\section{CONCLUSIONS AND POLICY RECOMMENDATIONS}

The study finds that several resilience factors, climatic factors, and nonclimatic factors are statistically significant to explain the household status of food security. It also finds that these factors differ between food secure and insecure groups.

Climate change is a major potential threat to household food security in Malaysia (Alam, Siwar and Al Amin, 2010; Alam and others, 2011). Therefore, to ensure sustainable household food security in the country, climate change must be integrated into the design of the Malaysian food security programmes. In addition, food security approaches must recognize climate change as an important driver. This integration would increase household capacity to adapt to climatic change. At the same time, climate change adaptation approaches and strategies to reduce vulnerability to climate change would also increase household food security.

Prioritization of needs for investment targeted at increasing food security adaptation to climate change is important. Climate change adaptations are concentrated on improving the potential of people, especially the most vulnerable groups, towards adapting to climate change. This involves extending support for livelihoods that are climate-resilient, reducing on disaster risk, advocacy, empowerment and social mobilization to curb the underlying causes of vulnerability (Alam and others, 2012b). To adequately deal with the effects of climate change on food security, plans have to be chalked out with a good analysis of the groups that are particularly marginal, as they are likely to be the most affected by climate change and have very limited capacities to cope with it.

Climate change affects groups that have always been at risk of food insecurity, but it also affects new groups who have become vulnerable to regional weatherchanging conditions (IPCC, 2007). Most vulnerable groups have already practiced some form of risk management, but their capability to adapt to climatic change is often limited due to their extremely restricted coping-up potential. Thus, the climate change adaptation techniques and food security should empower the groups that are socially excluded to lower their vulnerability and improve their resilience (Stern, 2007; Pielke and others, 2007; Thompson and Metz, 1997). Work on adaptation must 
address food security as a major challenge faced by the populations that are vulnerable to climate, while food security plans, in most cases, give people the capability to adapt to changes in climate, specifically when climate change is taken explicitly into consideration.

Mitigation options are important when planning for the long term. People who are vulnerable should be empowered and encouraged to adapt to climate change by developing resilience through investments in health, social protection, education, infrastructure, and other methods. Monitoring weather extremes and design strategies for disaster preparation is also very important. Given these effects and the resources needed to adapt them, resources applied towards realizing the Sustainable Development Goals might be integrated into mitigation programmes of climatic change. Furthermore, the private sector should advocate mitigation methods, such as energy efficiency, renewable energy, developments and infrastructure, which includes, for example, dams, flood-resistant storage facilities, cyclone shelters and techniques for lowering water loss in distribution systems.

Finally, local, national, and regional administrations must be provided with sufficient resources to deal with the challenges of climate change. They should concentrate on the building of capacity in communities that are particularly at risk of food insecurity, as well as climatic changes. New studies should also be undertaken to validate or reject the overall findings of this study. The findings of the study are empirically very new. Therefore, there is a scope to explore this issue further. The results of this study can be investigated further and validated against other socioeconomic factors, demographic factors, different locations, different economic groups, and different measurements of the level of food security. 


\section{REFERENCES}

Abdulai, Awudu, and Anna CroleRees (2001). Constraints to income diversification strategies: evidence from Southern Mali. Food Policy, vol. 26, No. 4, pp. 437-452.

Alam, Md. Mahmudul, Chamhur Siwar, and Abul Quasem Al-Amin (2010). Climate change adaptation policy guidelines for agricultural sector in Malaysia. Asian Journal of Environmental and Disaster Management, vol. 2, No. 4, pp. 463-469.

Alam, Md. Mahmudul, and others (2011). Farm level assessment of climate change, agriculture and food security issues in Malaysia. World Applied Sciences Journal, vol. 14, No. 3, pp. 431-442.

(2012a). Initiatives and challenges of agricultural crop sector in ECER Development Projects in Malaysia. American-Eurasian Journal of Agricultural \& Environmental Science, vol. 12, No. 7, pp. 922-931.

(2012b). Paddy farmers' adaptation practices to climatic vulnerabilities in Malaysia. Mitigation and Adaptation Strategies for Global Change, vol. 17, No. 4, pp. 415-423.

(2014). Impacts of climatic changes on paddy production in Malaysia: micro study on IADA at North West Selangor. Research Journal of Environmental and Earth Sciences, vol. 6, No. 5 , pp. 251-258.

(2016a). Climate change and food security of the Malaysian East Coast poor: a path modeling approach. Journal of Economic Studies, vol. 43, No. 3, pp. 458-474.

(2016b). Food security and low-income households in the Malaysian East Coast Economic Region: an empirical analysis. Review of Urban \& Regional Development Studies, vol. 28, No. 1, pp. 2-15.

Ali, R., and A.K. Ali (2009). Estimating the prospective impacts of global warming on Malaysian agriculture. Proceeding of $2^{\text {nd }}$ National Conference on Agro-Environment 2009, MARDI. Malaysia, 24-26 March.

Arshad, F.M., M.N. Shamsudin, and R. Saleh (1999). Food security in Malaysia. Presented at Seminar on International Trade and Food Security. Asian Productivity Organization, Tokyo.

Baker, J.T., and L.H. Allen, Jr. (1993). Contrasting crop species responses to CO2 and temperature: rice, soybean and citrus. Vegetatio, vol. 104, No. 1, pp. 239-260.

Checkley, William, and others (2000). Effects of El Niño and ambient temperature on hospital admissions for diarrhoeal diseases in Peruvian children. The Lancet, vol. 355, pp. 442-450.

Cline, William R. (2007). Global Warming and Agriculture: Impact Estimates by Country. Washington, D.C.: Center for Global Development and Peterson Institute for International Economics.

Coates, Jennifer, Anne Swindale, and Paula Bilinsky (2007). Household Food Insecurity Access Scale (HFIAS) for Measurement of Household Food Access: Indicator Guide, vol. 3. Washington, D.C.: Food and Nutrition Technical Assistance Project, Academy for Educational Development.

Cristofar, Sharron P., and P. Peter Basiotis (1992). Dietary intakes and selected characteristics of women ages 19-50 years and their children ages 1-5 years by reported perception of food sufficiency. Journal of Nutrition Education, vol. 24, No. 2, pp. 53-58. 
Cruz, Rex Victor, and others (2007). Asia. In Climate Change 2007: Impacts, Adaptation and Vulnerability. Contribution of Working Group II to the Fourth Assessment Report of the Intergovernmental Panel on Climate Change, M.L. Parry and others, eds., Cambridge, U.K.: Cambridge University Press.

Economic Commission for Africa (ECA) (2004). Land Tenure Systems and Their Impacts on Food Security and Sustainable Development in Africa. Addis Ababa.

East Coast Economic Region Development Council (ECERDC) (2007). ECER Master Plan: economic drivers of the region - agriculture. Malaysia.

(2008). ECER Master Plan: success factors. Available from www.ecerdc.com.my/en/ master-plan/success-factors/. Accessed 18 July 2016.

Energy Information Administration (EIA) (2005). International Energy Annual 2005 - CO2 World Carbon Dioxide Emissions from the Consumption of Coal, 1980-2006 (Million Metric Tons of Carbon Dioxide). Washington, D.C.: Government of the United States.

Food and Agriculture Organization (FAO) (2003). Trade Reforms and Food Security: Conceptualizing the Linkages. Rome.

(2005). The State of Food Insecurity in the World 2005. Rome.

(2007). High prices and volatility in agricultural commodities. Food Outlook, November. Available from www.fao.org/docrep/010/ah876e/ah876e13.htm\#21.

(2008). Climate change and food security: a framework document. Rome: FAO Interdepartmental Working Group on Climate Change.

Fartahun, Melaku, and others (2007). Women's involvement in household decision making and strengthening social capital are crucial factors for child survival in Ethiopia. Acta Paediatrica, vol. 96, No. 4, pp. 582-589.

Field, Andy (2000). Discovering Statistics Using SPSS for Windows. Thousand Oaks, California: Sage Publications.

Frankenberger, Timothy R. (1992). Indicators and data collection methods for assessing household food security. In Household Food Security: Concepts, Indicators, and Measurements: a Technical Review, Simon Maxwell and Timothy R. Frankenberger, eds. New York: UNICEF; Rome: IFAD.

Hindin, Michelle J. (2006). Women's input in household decision and their nutritional status in three resource-constrained settings. Public Health Nutrition, vol. 9, No. 4, pp. 485-493.

Intergovernmental Panel on Climate Change (IPCC) (2007). Climate Change 2007 - Impacts, Adaptation and Vulnerability. Contribution of Working Group II to the Fourth Assessment Report of IPCC. Cambridge, U.K.: Cambridge University Press.

Iram, Uzma, and Muhammad S. Butt (2004). Determinants of household food security: an empirical analysis for Pakistan. International Journal of Social Economics, vol. 31, No. 8, pp. 735-766.

Kovats, R.S., and others (2004). The effect of temperature on food poisoning: time series analysis in 10 European countries. Epidemiology and Infection, vol. 132, No. 3, pp. 443-453.

Kundzewicz, Zbigniew W., and others (2007). Freshwater resources and their management. In Climate Change 2007: Impacts, Adaptation and Vulnerability. Contribution of Working Group II to the Fourth Assessment Report of the Intergovernmental Panel on Climate Change, Martin L. Parry and others, eds. Cambridge, U.K.: Cambridge University Press. 
Lovendal, Christian Romer, and Macro Knowles (2006). Tomorrow's hunger: a framework for analysing vulnerability to food security. Research Paper, No. 2006/119. Helsinki: United Nations University - World Institute for Development Economic Research.

Mimura, Nobuo, and others (2007). Small islands. In Climate Change 2007: Impacts, Adaptation and Vulnerability. Contribution of Working Group II to the Fourth Assessment Report of the Intergovernmental Panel on Climate Change, Martin L. Parry and others, eds. Cambridge, U.K.: Cambridge University Press.

Ministry of Science, Technology and the Environment (MOSTE) (2001). National Response Strategies to Climate Change. Putrajaya, Malaysia.

Myntti, Cynthia (1993). Social determinants of child health in Yemen. Social Science \& Medicine, vol. 37, No. 2, pp. 233-240.

National Hydraulic Research Institute of Malaysia (NAHRIM) (2006). Final Report: Study of the Impact of Climate Change on the Hydrologic Regime and Water Resources of Peninsular Malaysia. National Hydraulic Research Institute of Malaysia (NAHRIM) and California Hydrologic Research Laboratory (CHRL), Malaysia.

Negatu, Workneh. (2006). Determinants of small farm household food security: evidence from south Wollo, Ethiopia. Ethiopian Journal of Development Research, vol. 28, No. 1, pp.1-29.

Nyariki, Dickson M., and Steve Wiggins (1997). Household food insecurity in Sub-Saharan Africa: lesson from Kenya. British Food Journal, vol. 99, No. 7, pp. 249-262.

Olson, Christine M., and others (1997). Factors contributing to household food insecurity in rural upstate New York. Family Economics and Nutrition Review, vol. 10, pp. 2-17.

Pfeiffer, James, Stephen Gloyd, and Lucy Ramirez Li (2001). Intra-household resource allocation and child growth in Mozambique: an ethnographic case-control study. Social Science \& Medicine, vol. 53, No. 1, pp. 83-97.

Piaseu, Noppawan (2006). Factors affecting food insecurity among urban poor in Thailand. South African Journal of Clinical Nutrition, vol. 18, pp. 156-161.

Pielke, Roger, and others (2007). Lifting the taboo on adaptation. Nature, vol. 445, No. 7128, pp. 597-598.

Rose, Donald, and Peter P. Basiotis (1995). Improving federal efforts to assess hunger and food insecurity. FoodReview, vol. 18, No. 1 (Jan-Apr), pp. 18-23.

Singh, S., and others (1996). Simulated impact of climate change on rice production in Peninsular Malaysia. Proceeding of National Conference on Climate Change. UPM, Malaysia.

Stern, Nicholas (2007). The Economics of Climate Change: the Stern Review. Cambridge, U.K.: Cambridge University Press.

Tashiro, Toru, and lan F. Wardlaw (1989). A comparison of the effect of high temperature on grain development in wheat and rice. Annals of Botany, vol. 64, No. 1, pp. 59-65.

Thompson, Anne, and Manfred Metz (1997). Implications of Economic Policy for Food Security: A Training Manual. Training Materials for Agricultural Planning, 40. Rome: FAO.

(1998). Implications of Economic Policy for Food Security: A Training Manual. Rome. FAO and the German Agency for Technical Cooperation (GTZ). 
Tisdell, Clem (1996). Economic indicators to assess the sustainability of conservation farming projects: an evaluation. Agriculture, Ecosystems and Environment, vol. 57, No. 2-3, pp. 117-131.

von Braun, Joachim. (2007). The world food situation: new driving forces and required actions. Food Policy Report. Washington, D.C.: International food Policy Research Institute.

Yamane, Taro (1967). Statistics: An Introductory Analysis, edition 2. New York: Harper and Row; Tokyo: John Weatherhill.

Zimmerman, M., and others (2007). Variability of total and Pathogenic Vibrio Parahaemolyticus Densities in Northern Gulf of Mexico water and oysters. Applied and Environmental Microbiology, vol. 73, No. 23, pp. 7589-7596. 


\section{APPENDIX}

\section{List of the variables}

Y1 Household food availability in the last one month, where available enough of the kinds of food you want to eat $=1$, others $=0$

Y2 Household status of food accessibility, where food secure access $=1$, others $=0$

X1 Education level, where illiterate $=1$, primary $=2$, secondary $=3$, certificate $=4$

X2 Number of school going children, where no school going children $=1$, $1-2$ children $=2,3$ children $=3,4-5$ children $=4$, more than 5 children $=5$

X3 Household poverty/economic status, where marginally non-poor $=1$, recently marginally non-poor $=2$, poor $=3$, hard core poor $=4$

X4 Spouse doing job, where yes $=1$, no $=0$

X5 Head of household having supplementary job, where yes $=1$, no $=0$

X6 Earning ratio (earning family member/total family member) is coded in 1-5 scale based on equal value for every $20 \%$ ratio value, where $0-20 \%, 21-40 \%$, $41-60 \%, 61-80 \%$, and $81-100 \%$ are coded as $1,2,3,4,5$, respectively

X7 Household having any savings, where yes $=1$, no $=0$

X8 Locality, where urban $=1$, rural $=0$

X9 Ownership of house, where yes $=1$, no $=0$

X10 Type of home, where wood made $=1$, mixed $=2$, brick $=3$

X11 Household having any transport for buying food, where yes $=1$, no $=0$

X12 Household buying bulk amount of food, where yes $=1$, no $=0$

X13 Household having neat and clean kitchen and dining place, where yes $=1$, no $=0$

X14 Household having a hygienic sanitation facility, where strongly disagree $=1$, disagree $=2$, not sure $=3$, agree $=4$, strongly agree $=5$ 
X15 Household managing waste properly, where strongly disagree $=1$, disagree $=2$, not sure $=3$, agree $=4$, strongly agree $=5$

X16 Household having knowledge about maintaining nutritious and hygienic way of cooking and washing food, where strongly disagree $=1$, disagree $=2$, not sure $=3$, agree $=4$, strongly agree $=5$

X17 Household having knowledge about taking precaution against dengue, malaria, etc., where strongly disagree $=1$, disagree $=2$, not sure $=3$, agree $=4$, strongly agree $=5$

X18 The effectiveness of current food distribution process in Malaysia, where very low $=1$, low $=2$, normal $=3$, high $=4$, very high $=5$

X19 Current road and transportation facility for food distribution process in Malaysia, where very low $=1$, low $=2$, normal $=3$, high $=4$, very high $=5$

X20 Availability of expected food in the local market, where very low $=1$, low $=2$, normal $=3$, high $=4$, very high $=5$

X21 Sufficiency of expected food in the local market, where very low $=1$, low $=2$, normal $=3$, high $=4$, very high $=5$

X22 Current prices of general food items, where very low $=1$, low $=2$, normal $=3$, high $=4$, very high $=5$

X23 Current difference between rural and city food prices, where very low $=1$, low $=2$, normal $=3$, high $=4$, very high $=5$

X24 High prices of food cause household food shortage, where very low $=1$, low $=2$, normal $=3$, high $=4$, very high $=5$

X25 Current level of household income, where very low $=1$, low $=2$, normal $=3$, high $=4$, very high $=5$

X26 Low level of income cause household food shortage, where very low $=1$, low $=2$, normal $=3$, high $=4$, very high $=5$

X27 Ready budget arrangement to buy food anytime, where very low $=1$, low $=2$, normal $=3$, high $=4$, very high $=5$

X28 Availability of discount or offer on food price in the local market, where very low $=1$, low $=2$, normal $=3$, high $=4$, very high $=5$ 
X29 The effectiveness of current food distribution process in Malaysia, where very low $=1$, low $=2$, normal $=3$, high $=4$, very high $=5$

X30 Dependency on common resources for cattle or livestock feeding, where very low $=1$, low $=2$, normal $=3$, high $=4$, very high $=5$

X31 Current competition among people for common resources, where very low $=1$, low $=2$, normal $=3$, high $=4$, very high $=5$

X32 Current expenditure for feeding and medicine of cattle and livestock, where very low $=1$, low $=2$, normal $=3$, high $=4$, very high $=5$

X33 Difference between rural and city food quality, where very low $=1$, low $=2$, normal $=3$, high $=4$, very high $=5$

X34 Food quality or nutrition level in local market, where very low $=1$, low $=2$, normal $=3$, high $=4$, very high $=5$

X35 Food quality on food safety in local market, where very low $=1$, low $=2$, normal $=3$, high $=4$, very high $=5$

X36 Quality of drinking water, where very low $=1$, low $=2$, normal $=3$, high $=4$, very high $=5$

X37 Stability of food price, where very low $=1$, low $=2$, normal $=3$, high $=4$, very high $=5$

X38 Price variation among shops in the local market, where very low $=1$, low $=2$, normal $=3$, high $=4$, very high $=5$

X39 Access of quick credit to buy food, where very low $=1$, low $=2$, normal $=3$, high $=4$, very high $=5$

X40 Stability of food supply, where very low $=1$, low $=2$, normal $=3$, high $=4$, very high $=5$

X41 Unavailability of food in market leading food shortage, where very low $=1$, low $=2$, normal $=3$, high $=4$, very high $=5$

X42 Agencies support for household food security, where very low $=1$, low $=2$, normal $=3$, high $=4$, very high $=5$

X43 Current level of incidences of mosquitos, insects, pest, etc., where very low $=1$, low $=2$, normal $=3$, high $=4$, very high $=5$ 
X44 Current level of incidences of disease like dengue, malaria, heat stretch, cold, skin disease, etc., where very low $=1$, low $=2$, normal $=3$, high $=4$, very high $=5$

X45 Occurrences of natural disasters such as flood, cyclone, landslides, etc. at local level, where very low $=1$, low $=2$, normal $=3$, high $=4$, very high $=5$

X46 Climatic issues and related disease reduce income, where yes $=1$, no $=0$

X47 Climatic issues affect household food collection system, where strongly disagree $=1$, disagree $=2$, not sure $=3$, agree $=4$, strongly agree $=5$

X48 Climatic issues affect household food storage system (e.g. refrigerator, packaging), where strongly disagree $=1$, disagree $=2$, not sure $=3$, agree $=4$, strongly agree $=5$

X49 Climatic issues affect household food storage process (e.g. dry, salty, oily), where strongly disagree $=1$, disagree $=2$, not sure $=3$, agree $=4$, strongly agree $=5$

X50 Climatic issues increase household food storage cost, where strongly disagree $=1$, disagree $=2$, not sure $=3$, agree $=4$, strongly agree $=5$

X51 Climatic issues affect household usage or utilization of land, where strongly disagree $=1$, disagree $=2$, not sure $=3$, agree $=4$, strongly agree $=5$

X52 Climatic issues reduce normal food test, where strongly disagree $=1$, disagree $=2$, not sure $=3$, agree $=4$, strongly agree $=5$

X53 Climatic issues reduce food longevity, where strongly disagree $=1$, disagree $=2$, not sure $=3$, agree $=4$, strongly agree $=5$

X54 Climatic issues affect household food choice and habit, where strongly disagree $=1$, disagree $=2$, not sure $=3$, agree $=4$, strongly agree $=5$

X55 Climatic issues affect household cooking system (e.g. cooking by gas or stove not by woods), where strongly disagree $=1$, disagree $=2$, not sure $=3$, agree $=4$, strongly agree $=5$

X56 Climatic issues affect cooking time and amount (e.g. large amount of cooking together or several time cooking for hot food or several times heating for not rotating), where strongly disagree $=1$, disagree $=2$, not sure $=3$, agree $=4$, strongly agree $=5$ 
X57 Climatic issues cause to eat outside or buy ready food from outside, where strongly disagree $=1$, disagree $=2$, not sure $=3$, agree $=4$, strongly agree $=5$

X58 Climatic issues affect the environment and cleanness of kitchen, where strongly disagree $=1$, disagree $=2$, not sure $=3$, agree $=4$, strongly agree $=5$

X59 Climatic issues affect household waste management, where strongly disagree $=1$, disagree $=2$, not sure $=3$, agree $=4$, strongly agree $=5$

X60 Climatic issues affect home sanitation system, where strongly disagree $=1$, disagree $=2$, not sure $=3$, agree $=4$, strongly agree $=5$

X61 Climatic issues hamper food aid services and food supports programme, where strongly disagree $=1$, disagree $=2$, not sure $=3$, agree $=4$, strongly agree $=5$

X62 Climatic issues increase short term food prices, where strongly disagree $=1$, disagree $=2$, not sure $=3$, agree $=4$, strongly agree $=5$

X63 Climatic issues cause to increase food price in restaurant, where strongly disagree $=1$, disagree $=2$, not sure $=3$, agree $=4$, strongly agree $=5$ 